\title{
JOB CREATION, JOB DESTRUCTION, AND THE REAL EXCHANGE RATE
}

\author{
Michael W. Klein \\ Scott Schuh \\ Robert K. Triest \\ Working Paper 7466 \\ http://www.nber.org/papers/w7466
NATIONAL BUREAU OF ECONOMIC RESEARCH 1050 Massachusetts Avenue
Cambridge, MA 02138
January 2000

Klein gratefully acknowledges financial support from the W.E. Upjohn Institute for Employment Research. Joshua Congdon-Martin and Catherine Humblet provided excellent research assistance. Research results and conclusions expressed are those of the authors and do not necessarily indicate concurrence by the Federal Reserve Bank of Boston or the Board of Governors of the Federal Reserve System. This paper does not contain or use confidential Census Bureau data. The views expressed herein are those of the authors and not necessarily those of the National Bureau of Economic Research.

C 2000 by Michael W. Klein, Scott Schuh, and Robert K. Triest. All rights reserved. Short sections of text, not to exceed two paragraphs, may be quoted without explicit permission provided that full credit, including (C) notice, is given to the source. 
Job Creation, Job Destruction, and the Real Exchange Rate

Michael W. Klein, Scott Schuh, and Robert K. Triest

NBER Working Paper No. 7466

January 2000

JEL No. F4

\section{ABSTRACT}

This paper contributes to an understanding of internationally generated adjustment costs by demonstrating a statistically significant and economically relevant effect of the real exchange rate on job creation and job destruction in U.S. manufacturing industries over the period 1973 to 1993 . The responsiveness of these gross job flows to the real exchange rate reflects pervasive heterogeneity with respect to international conditions across firms, even within narrowly defined industries. We document this heterogeneity and show that the responsiveness of job flows to movements in the real exchange rate varies with the industry's openness to international trade. We also show an asymmetry in the responsiveness of job flows to the real exchange rate; appreciations play a significant role in job destruction, but job flows do not respond significantly to dollar depreciations.

Michael W. Klein

Fletcher School of Law \& Diplomacy

Tufts University

Medford, MA 02155

and NBER

mklein@tufts.edu

Robert K. Triest

Research Department

Federal Reserve Bank of Boston

600 Atlantic Avenue

Boston, MA 02106

robert.triest@bos.frb.org
Scott Schuh

Research Department

Federal Reserve Bank of Boston

600 Atlantic Avenue

Boston, MA 02106

scott.schuh@bos.frb.org 


\section{Introduction: International Sources of Labor Mar- ket Churning}

The gains from international trade are obtained through the reallocation of resources to their most productive uses. This reallocation is not costless, however, and a full understanding of the overall impact of trade must consider both efficiency benefits and adjustment costs. Indeed, much of the debate over the net benefits of openness concerns the size of these adjustment costs, especially those arising from changes in employment. As noted in the 1998 Economic Report of the President, "The public debate over trade liberalization ... [has] focused on the distributional impact of increased trade. This issue arises from the tendency of increased trade to favor some domestic industries while putting others at a disadvantage" (pp. 238-39).

As suggested by this quote, an important source of internationally generated adjustment costs is changing patterns of employment that, in turn, reflect responses to movements in the real exchange rate. This role of the real exchange rate arises for two reasons. First, the volatility of the multilateral U.S. real exchange rate makes it a likely source of changing employment patterns between sectors selling internationally traded goods (such as manufacturing) and other sectors selling goods and services that do not directly face international competition. Furthermore, a given movement in the real exchange rate can generate a wide range of responses within traded-goods sectors, since exposure to international competition varies widely, even among firms within narrowly defined industries (Bernard and Jensen 1995).

This paper contributes to an understanding of internationally generated adjustment costs by demonstrating a statistically significant and economically important effect of the real exchange rate on gross job flows in manufacturing industries in the United States. Gross job flows consist of the total number of employment positions gained (job creation) and the total number of employment positions lost (job destruction) by all firms within a sector. An associated measure of labor market churning, job reallocation, is the sum of job creation and job destruction. ${ }^{1}$ These gross job flow measures are more closely associated with labor market adjustment than the more conventional measure of net employment change, which represents the difference between the job creation rate and the job destruction rate, since net change does not fully account for intrasectoral job flows. Previous research has

\footnotetext{
${ }^{1}$ See Davis, Haltiwanger and Schuh (1996) for an extensive discussion of the role of job creation and destruction in U.S. manufacturing sectors.
} 
focused almost exclusively on the effects of international factors on net employment flows. ${ }^{2}$

Gross job flows are an important aspect of the manufacturing sector of the United States. For example, the average annual reallocation rate in manufacturing over the period 1973 to 1993 was 19 percent, while during the same period the average net decrease in overall manufacturing employment was 1.4 percent. Through reallocation, workers move to more productive and more remunerative positions as new opportunities become available and as new jobs are created. But labor market reallocation across sectors and regions has a costly side as well. In the wake of job destruction, workers could experience a protracted period of unemployment during their search for a new job. Successful reemployment may require retraining, which itself demands time and resources, or moving to another part of the country. Furthermore, firm-specific skills, and possibly sector-specific skills, are rendered useless with job destruction and, as a consequence, wages in new jobs may not match previous wages.

Since the basis of simultaneous job creation and job destruction is heterogeneity across firms, we present evidence in the next section on the extent of heterogeneity with respect to international competition in U.S. manufacturing. Openness among manufacturing industries increases over time but the increasing divergence in the degree of openness across industries is even more striking. This divergence occurs even within seemingly narrow categories of manufacturing industries. Taking this pervasive heterogeneity in openness as a starting point, we present a model in Section 3 in which simultaneous job creation and job destruction arise within a sector in response to movements in the real exchange rate. This model motivates our estimating equation.

Section 4 presents the results from our econometric analysis of the effects of the real exchange rate on job creation and destruction. Job destruction in 4-digit SIC industries responds significantly to real exchange rate appreciations. For example, we estimate that the real exchange rate appreciation of the early 1980s caused a cumulative increase in the job destruction rate of 14.4 percentage points over five years, controlling for many other aggregate and industry-level factors. This overall effect for manufacturing is accompanied by divergent movements across more narrowly defined manufacturing sectors. We find statistically significant and economically relevant evidence of heterogeneous responsiveness of job

\footnotetext{
${ }^{2}$ See, for example, Grossman (1982), Branson and Love (1988), Revenga (1992), Sachs and Shatz (1994), Goldberg and Campa (1997) and Burgess and Knetter (1998). Gourinchas (1999) does considers the effect of international factors on gross job flows. In a related vein, Kletzer (1998b) studies data on gross worker flows.
} 
destruction to appreciations in the exchange rate resulting from differences in the degree of openness among industries. This suggests an international source of job churning among manufacturing industries. Interestingly, however, job creation does not respond significantly to changes in the real exchange rate.

\section{Job Flows and Openness Across Industries and Across Time}

The focus of this paper is the study of how job flows in detailed industries respond differently to changes in the real exchange rate and thus give rise to job reallocation. An initial issue, then, is the extent of heterogeneity among manufacturing industries, both with respect to job flows and with respect to international exposure. In this section we present evidence on these issues.

In Section 2.1 we investigate the heterogeneity in job creation and job destruction among manufacturing industries. We show that much of the cross-sectional variation in job flows occurs within narrowly defined industries rather than between broader industry groups. But the main source of the time series crosssectional variation in the job flow rates of 4-digit industries is temporal variation, rather than any persistent cross-sectional differences in the degree of job churning. We show that the real exchange rate significantly affects the temporal behavior of the job destruction rate for the overall manufacturing sector.

The focus of our interest, however, is the differential responses to movements in the real exchange rate among manufacturing industries. A particular industry's response to the real exchange rate is likely linked to how open it is to international trade. Therefore, the cross-sectional variation in job creation and job destruction induced by the real exchange rate reflects, in part, cross-sectional variation in openness. In Section 2.2 we present some information on openness across manufacturing industries in the United States. We show that openness among manufacturing has grown markedly over the past three decades. More to the point for the focus of this paper, the dispersion of openness among manufacturing sectors has also grown. We find that openness among manufacturing industries is not well explained by standard industrial groupings, a result with important implications for the manner in which we conduct our empirical investigation. 


\subsection{Gross Job Flows in Manufacturing}

It has been noted elsewhere that gross job flow data reveal significant churning in the labor market for manufacturing jobs in the United States. ${ }^{3}$ In this section we define job creation and job destruction, the components of gross job flows. We present the empirical evidence on job destruction and job creation across all manufacturing sectors, along with the time path of the real exchange rate. We also examine the degree of heterogeneity in gross job flows across sectors.

Our data on industry-level job creation and destruction come from Davis, Haltiwanger, and Schuh (1996), in file RZI4.DAT, constructed from the panel of manufacturing plants in the Census Bureau's Longitudinal Research Database (LRD). Our data on industry-level international trade come from the NBER export and import data base described in Abowd (1990) and Feenstra $(1996,1997){ }^{4}$ These job flows and trade data are supplemented with data on other manufacturing activity from the NBER Productivity Database described in Bartelsman and Gray (1996). ${ }^{5}$ This combined data set provides a panel of annual data for 442 4-digit manufacturing industries over the period 1973 to $1993 .^{6}$

Job creation rates and job destruction rates are calculated from plant-level net employment changes. Let $z_{\text {eit }}$ be the level of a manufacturing plant's employment, where the subscripts denote plant $(e)$, industry $(i)$, and time $(t)$, and let $\Delta$ denote the first-difference operator, $\Delta z_{t}=z_{t}-z_{t-1}$. Following Davis, Haltiwanger, and Schuh (1996), we define job creation in a manufacturing plant as:

$$
c_{e i t}= \begin{cases}\Delta z_{e i t} & \text { if } \Delta z_{e i t}>0 \\ 0 & \text { otherwise }\end{cases}
$$

and plant-level job destruction is

$$
d_{e i t}= \begin{cases}\left|\Delta z_{e i t}\right| & \text { if } \Delta z_{e i t}<0 \\ 0 & \text { otherwise. }\end{cases}
$$

For establishments that increase their level of employment over a given time period, $c_{e i t}$ is positive and $d_{e i t}$ is zero, while for establishments that reduce their employment, $c_{e i t}$, is zero and $d_{e i t}$ is positive.

\footnotetext{
${ }^{3}$ See, especially, Davis, Haltiwanger, and Schuh (1996).

${ }^{4}$ See also ftp://ftp.ssds.ucdavis.edu/pub/Econ/Feenstra/UStrade.

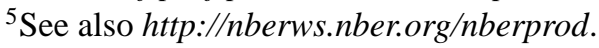

${ }^{6}$ Our data are annual because the trade and productivity data are only available at that frequency. In principle, it would be preferable to have higher frequency data when studying exchange rates. However, the annual data actually are advantageous because they omit high frequency transitory fluctuations in the exchange rate that probably do not induce job creation and destruction responses because job flows are costly and time-consuming.
} 
The gross job creation rate in industry $i$ in year $t, C_{i t}$, represents the sum of all positive employment changes across all establishments in that industry in that year divided by total industry employment that year. ${ }^{7}$ Likewise, the corresponding gross job destruction rate, $D_{i t}$, represents the sum of the absolute value of all negative employment changes across all establishments in that industry divided by total industry employment. The average value of the annual job creation rate in manufacturing over the period 1973 to 1993 was 8.8 jobs created per 100 positions each year, while the comparable average rate of job destruction was 10.2 jobs destroyed per 100 positions each year (Schuh and Triest 1998). Reallocation within industry $i$ in year $t, R_{i t}$, is defined as the sum of its creation and destruction rates $\left(R_{i t}=C_{i t}+D_{i t}\right)$, while its rate of net change in employment, $N_{i t}$, can be calculated by subtracting the job destruction rate from the job creation rate $\left(N_{i t}=\right.$ $C_{i t}-D_{i t}$ ). Thus, the average annual rate of job reallocation in manufacturing was 19 percent between 1973 and 1993 while, during this period, the manufacturing sector saw an average net decline of 1.3 jobs per 100 positions (numbers do not add due to rounding).

Statistics on the average annual values of gross job flows fail to reveal the wide swings that have sometimes occurred over our sample period. Figure 1 shows that the rates gross job flows vary widely over time, as shown in Figure 1, for the manufacturing sector over the period 1973 to $1992 .{ }^{8}$ The reallocation rate exceeded 20 percent in half the years of the sample, reaching a high of 24 percent in 1983. The figure demonstrates that the job destruction rate is more volatile than the job creation rate, with the job destruction rate exceeding 15 percent in three years, 1975, 1982, and 1983.

Figure 1 also provides some preliminary evidence on the correlation between manufacturing gross job flows and the business cycle. Shaded bars in the figure represent periods of recession. The data in the figure suggest that the job destruction rate is strongly countercyclical, while the job creation rate is procyclical. The figure also depicts the multilateral real exchange rate over the sample period, with an increase in this measure indicating an appreciation of the dollar. The job destruction rate appears to be linked to the real exchange rate, exhibiting higher values when the real exchange rate is strong and lower values when the real ex-

\footnotetext{
${ }^{7}$ For reasons described in Davis, Haltiwanger, and Schuh (1996), the gross job flows are defined as March-to-March changes rather than calendar-year changes like our other data. We match data sampling periods as best as possible using lags. About a one-quarter mismatch remains, but it does not appear to seriously affect the timing of relationships between variables at annual frequencies.

${ }^{8}$ In this figure, the annual job flows data have been interpolated to a quarterly frequency to permit accurate plotting of business cycle dates.
} 

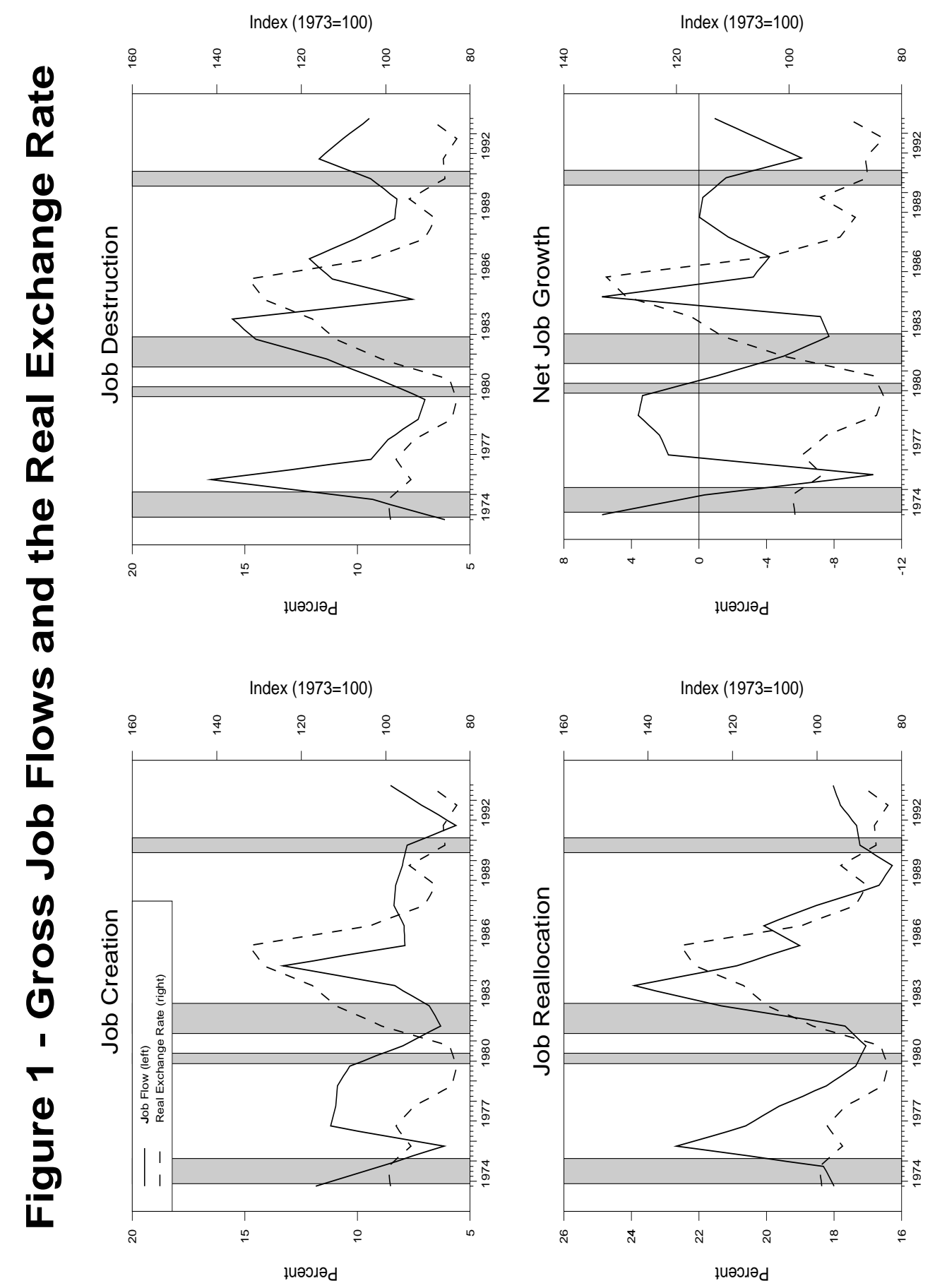
change rate is weak. The job creation rate does not track movements in the real exchange rate as closely.

The relationships suggested by inspection of the figures are supported by simple regressions using the annual job creation rate in manufacturing, $C_{t}$, the annual job destruction rate in manufacturing, $D_{t}$, the lagged percentage change in the real exchange rate, $\% \Delta R E R_{t-1}$, and the lagged percentage change in manufacturing industrial production, $\% \triangle I P M_{t-1}$. Estimating these equations over the period 1974 to 1993 , we find

$$
\begin{aligned}
C_{t} & =\underset{(0.51)}{8.28} \underset{(0.05)}{0.015 \% \Delta R E R_{t-1}}+\underset{(0.09)}{0.10 \% \Delta I P M_{t-1}} \\
R^{2} & =0.07 \quad D W=1.63 \quad n=19 \\
D_{t} & =\underset{(0.56)}{11.12}+\underset{(0.056)}{0.12} \% \Delta R E R_{t-1}-\underset{(0.10)}{0.24 \% \Delta I P M_{t-1}} \\
R^{2} & =0.41 \quad D W=2.07 \quad n=19
\end{aligned}
$$

where standard errors are in parentheses. The coefficients in these regressions are all of the expected sign, and the coefficients in the destruction equation are significant at the 5 percent level.

These results suggest an important role for the real exchange rate in job destruction; for example, over the period from 1982 to 1986, the job destruction rate in manufacturing averaged 12.2 percent, 2 full percentage points above its unconditional sample average of 10.2 percent. The average value of the lagged change in the exchange rate during that time was 8.9 percent. Thus, more than 50 percent of the average increase in the job destruction rate $(8.9 \times 0.12=1.07$ percentage points of the 2 percentage point rise) may be attributable to the real exchange rate appreciation.

These results contrast with the evidence presented by Davis, Haltiwanger and Schuh (1996) who find "Strikingly, ... no systematic relationship between the magnitude of gross job flows and exposure to international trade" (p. 48). This conclusion is based upon an analysis in which 4-digit industries are sorted by two measures of foreign trade exposure, the import penetration ratio and the export share. Industries are divided into 5 categories based on these exposure measures. There is no evidence, using this method, that the average rates of job destruction, job creation or job reallocation over the period 1973 to 1988 are associated with differences in international exposure (see their Table 3.5). But one would not expect to find that the factors that determine long-run import penetration or long-run export share across industries, such as resource endowments and geography, are 
correlated with the those that determine long-run gross labor flows across industries, such as the costs of hiring and firing. The evidence presented here, however, suggests that international factors may be an important source of the time series behavior of job destruction, job creation, and job reallocation.

In Section 4 of the paper we investigate whether the real exchange rate is an important source of the cross-sectional time series behavior of job creation and destruction. While the regressions reported above suggest a role for the reallocative effects of the real exchange rate between the manufacturing and the nonmanufacturing sectors of the economy, an analysis of job reallocation within manufacturing requires consideration of the differential effects of the real exchange rate on job creation rates and job destruction rates at a much more disaggregated level. Differential cross-sectional responses to a common shock, such as to the exchange rate, requires cross-sectional variation in gross job flows. In this section we introduce this topic by addressing the degree of heterogeneity of job flows across disaggregated manufacturing industries.

The presence of simultaneous creation and destruction for the manufacturing sector as a whole is to be expected since there is evidence of a great deal of heterogeneity, even within narrowly defined industries. For example, we find either creation and no destruction or destruction and no creation for any 4-digit SIC industry in any year in only about two-tenths of 1 percent of all observations. In only about 2 percent of all observations is the rate of job destruction or the rate of job creation less than 1 percent. There are very few cases of low rates of job creation even if we consider only observations when job destruction was large. Job creation was less than 1 percent in only 1.8 percent of the cases when job destruction was above its national average value of 10.7 percent. Likewise, job destruction was less than 1 percent in only 1.1 percent of the cases when job creation was above its national average of 8.7 percent.

Table 1 provides a more systematic examination of heterogeneity in gross job flows among industries. This table displays the adjusted $R^{2}$ values from regressions of the annual rates of job creation and job destruction of 4-digit industries on different sets of dummy variables, using ANOVA. Column 1 reports the $R^{2}$ statistics from regressions in which a single dummy variable representing durable goods industries is used. The $R^{2}$ statistics reported in Column 2 are from regressions with 19 dummy variables that are used to control for the set of 20 2-digit industries, while the statistics in Columns 3 and 4 are from regressions controlling for the set of 143 3-digit industries and the full set of 4424 -digit industries, respectively. In each case, the adjusted $R^{2}$ reflects the extent of job creation or job destruction explained by industry categories. If, for example, all 4-digit indus- 
Table 1: Job Flows Regressions on Industry Variables $\left(\bar{R}^{2}\right.$ values)

Industry Indicators

\begin{tabular}{lrrrr} 
& Durability & 2-digit & 3-digit & 4-digit \\
\hline No. of Variables & 1 & 19 & 142 & 441 \\
\hline 1973-1993 (9282 observations): & & & & \\
Job creation & .01 & .06 & .13 & .23 \\
Job destruction & .00 & .06 & .12 & .18 \\
\hline 1990 (442 observations): & & & & \\
Job creation & .00 & .07 & .18 & \\
Job destruction & .01 & .06 & .13 & \\
\hline
\end{tabular}

NOTE: Table entries are the adjusted $R^{2}$ values from regressions of job flow rates on a set of industry dummy variables.

tries within any 2-digit category had very similar measures of job creation, then we would find a large adjusted $R^{2}$ in a regression of job creation on a set of 2-digit dummy variables and little difference between this adjusted $R^{2}$ and the ones we would obtain for regressions of job creation on a set of 3-digit dummy variables or on a set of 4-digit dummy variables.

The top panel of Table 1 reports results for regressions using a pooled sample representing all 21 years for which we have job flows data. In this pooled data set, job creation rates and job destruction rates vary both over 4-digit industries and over time. The results in the table indicate that the adjusted $R^{2}$ values are only 0.23 for job creation and 0.18 for job destruction when these rates are regressed on a complete set of 4-digit industry dummy variables. This suggests that temporal variation in the job flow rates of 4-digit industries is a much more important contributor to their overall variance than are any persistent differences across 4-digit industries in the degree of job churning.

The bottom panel of Table 1 reports results that isolate the cross-sectional variation in openness by performing a comparable ANOVA using data from a single year, 1990. ${ }^{9}$ The results presented in the bottom panel show that very little of the cross-sectional variation in job flow rates among 4-digit industries in that year is due to systematic differences in job churn rates between more aggregated industry groups. For example, only 6 percent of the cross-sectional variation in

\footnotetext{
${ }^{9}$ Results from this particular year are broadly representative of results obtained from any other particular year.
} 
job destruction rates is explained by a 4-digit industry's membership in a 2-digit category, and only 13 percent is explained by its membership in a 3-digit industry category.

Heterogeneity in job creation and job destruction across industries due to movements in the real exchange rate should reflect, in part, heterogeneity in the exposure of these industries to international competition. In the next section we discuss the growth and heterogeneity of narrowly defined manufacturing industries as they relate to one measure of exposure to international competition.

\subsection{Growth and Heterogeneity in Openness}

It has been widely noted that the U.S. economy has become more open over time. But, as with many popular notions, the details behind this fact are both less well known and provide a more nuanced picture. In this section we confirm the presence of an overall growth in openness in manufacturing. But we also demonstrate that the change in openness over time varies widely across industries, with openness increasing among some industries while other industries remain largely closed.

The general increase in openness over time among U.S. manufacturing industries as well the increasingly divergent relationship among industries with respect to international trade is captured in Figure 2. In this figure, and throughout the rest of this section, we define openness as the sum of the value of an industry's exports plus imports as a proportion of the sum of that industry's domestic sales, exports, and imports. Figure 2 shows the range (10th to 90th percentiles), median value, lower quartile value, and upper quartile value of openness for 4-digit industries over the period 1958 to 1994.

This figure confirms the upward trend in openness over time, with the median value of the ratio of exports plus imports to shipments increasing from 4 percent in 1958 to 22 percent in 1994. This growth in the median value of this measure of openness proceeded somewhat unevenly over the sample, with relatively little change from the late 1950s until the end of the 1960s, when the average annual change in the median value of openness was 3.5 percent. The pace of the growth of openness quickened after 1972. Between 1972 and 1987 the median value of openness grew at an average annual rate of 5.0 percent. This growth has accelerated slightly in recent years, with an annual average growth rate of 5.25 percent between 1987 and 1994.

Perhaps the most striking aspect of Figure 2, however, is not the growth in the median value of openness from the late 1950 s to mid 1990s, but the increas- 
Figure 2: Distributions of Openness Over 4-Digit Industries

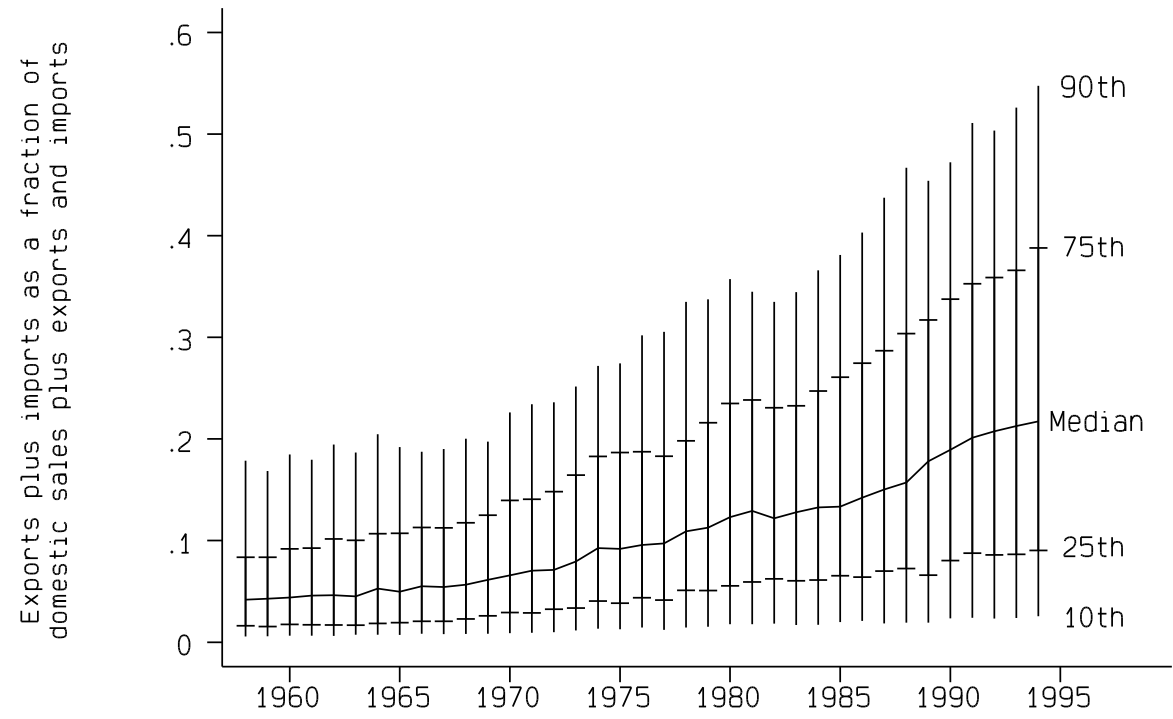

Note: Figure displays the time series of percentiles from the distributions of openness over 4-digit industries 
Table 2: Regression of 1990 Openness on Industry Indicator Variables

Industry Indicators

\begin{tabular}{lrrr} 
& Durability & 2-digit & 3-digit \\
\hline No. of variables & 1 & 19 & 142 \\
\hline$(442$ observations): & & & \\
$\bar{R}^{2}$ & 0.02 & 0.27 & 0.44 \\
\hline
\end{tabular}

NOTE: Durability refers to the distinction between durable goods (SIC 24-25 and 32-39) and nondurable goods (remaining SICs).

ingly divergent international exposure of 4-digit industries. While some industries throughout the period essentially had no direct international exposure, the value of openness at the 75th percentile of industries quadrupled, from 10 to 39 percent, and the 90 th percentile rose from 18 to 55 percent. This increase in openness at the top end of the distribution was not matched by a parallel increase in openness in absolute terms among the industries at the lower end. Thus the range of openness between 75th and 25th percentiles increased from 8 to 30 percentage points, and the range between the 90th and 10th percentiles increased from 17 percentage points to 52 percentage points.

The data presented in Figure 2 reveal the range of openness but not the composition of industries constituting high, medium, or low values of openness. One may expect similar levels of openness among industries producing common products. In fact, this is not the case. We regress the values of openness for 4-digit industries on three different sets of dummy variables representing more aggregated industry categories; the broad classification of durable / nondurable industries, the larger set of 202 -digit industry indicators and the set of 143 3-digit categories. In each case, the adjusted $R^{2}$ reflects the extent of openness explained by industry categories. The increase in $R^{2}$ from one regression to another shows the marginal difference explained by a more disaggregated set of industry indicators.

The results from each of these three regressions, using the measure of openness in 1990 for 4-digit industries, are presented in Table 2. This table shows that there is virtually no difference on average between the openness of durable and nondurable manufacturing industries, with an adjusted $R^{2}$ of only 0.02 in a regression using only one dummy variable to distinguish between nondurable and durable industries. The amount of variation in openness explained by membership in a particular 2-digit industry is also relatively small since the adjusted $R^{2}$ for a regression using 19 dummy variables to control for the 2-digit SIC industries 
Table 3: Transitions of 4 Digit Industries Between Openness Quintiles

\begin{tabular}{l|rrrrr|r}
\hline & \multicolumn{5}{|c|}{1993 quintile (range of openness) } & \\
1973 quintile & 1 & 2 & 3 & 4 & 5 & \\
\hline \hline $1(0-.07)$ & $(.07-.16)$ & $(.16-.26)$ & $(.26-.40)$ & $(.40-1)$ & Total \\
$2(.03-.06)$ & 78 & 17 & 3 & 1 & 1 & 100 \\
$3(.06-.12)$ & 18 & 40 & 24 & 14 & 5 & 100 \\
$4(.12-.19)$ & 6 & 26 & 40 & 20 & 8 & 100 \\
$5(.19-1)$ & 0 & 10 & 24 & 40 & 26 & 100 \\
\hline
\end{tabular}

NOTE: The table shows the percentage distribution of industries in each 1973 quintile across 1993 quintiles.

is 0.27 . Regressing openness on 3-digit industry dummy variables raises the adjusted $R^{2}$ to 0.44 , well above its value when using 2-digit industry dummies but still below one-half.

These results indicate a great deal of heterogeneity in the degree of openness, largely unrelated to differences among 2-digit or even 3-digit industry groupings. This suggests that substantial differences are likely in the extent to which real exchange rate movements affect job creation and destruction across the industries that constitute a particular 2-digit or even 3-digit industry.

Increasing heterogeneity over time, as depicted in Figure 2, may reflect the fact that the most open industries in 1958 became even more open over time while the most closed industries at the beginning of the period remained closed. Alternatively, the data shown in Figure 2 could also be consistent with significant churning, whereby industries that were relatively closed early in the sample period may have become more open over time, while other industries experienced little change in openness or even a decline. We present a transition matrix to address the question of the stability of the ranking of industries by openness over time.

The transition matrix in Table 3 presents the percentage distribution for quintiles with respect to openness in 1973 of the 4-digit industries against the respective percentage distributions for 1993 (the range of years for which we have job flows data for our regression analysis). This table demonstrates that relatively little reshuffling has occurred in the ranking of industries' degrees of openness. Fifty-two percent of the 4-digit industries stayed in the same openness quintile between 1973 and 1993 and 88 percent stayed in either the same quintile or moved 
to an adjoining quintile. Note, however, that the cutoff values of openness for each quintile more than doubled during this period, confirming the overall increase in openness we first noted in Figure 2.

These statistics offer an interesting depiction of the growth and heterogeneity of openness in United States manufacturing industries. The average degree of openness has increased enormously in recent decades. The tendency has been for all industries to become more open over time, but the biggest increase in openness has been in the industries that were initially most open. This has resulted in an increasingly large degree of heterogeneity in openness to trade across 4-digit manufacturing industries. Some industries have become strongly integrated into the global economy, but others have remained largely isolated from international competition. Very little of this heterogeneity is associated with differences between broad industry groups. Even within 3-digit industries, the variance in the importance of international trade is large.

These characteristics of openness and gross job flows are important to keep in mind as we formulate a model of the relationship between the real exchange rate and job creation and destruction. In the next section we develop a model, which we implement in Section 4, drawing on the insights provided here.

\section{Heterogeneity, Gross Job Flows, and the Real Ex- change Rate}

Simultaneous job creation and job destruction within a narrowly defined industry suggest an important role for heterogeneity among firms in that industry. There are two conceptually distinct ways of moving beyond a "representative firm" to model heterogeneity among firms in an industry. Firms may have structural differences such that a common shock has distinct effects across firms, or firms may have a common structure but face idiosyncratic shocks. ${ }^{10}$ We focus on the heterogeneity arising out of structural differences across firms, since the focus of this paper is an empirical investigation of the effect of an aggregate variable, the real exchange rate, on job creation and destruction.

\footnotetext{
${ }^{10}$ The independent effects of aggregate and idiosyncratic shocks on gross job flows have been studied by Mortensen and Pissarides (1994), among others. We abstract from idiosyncratic shocks here. While acknowledging that idiosyncratic shocks may be responsible for significant gross job flows, we assume that such shocks are independent of, and uncorrelated with, movements in the real exchange rate.
} 
It is important to note that structural differences alone will not generate simultaneous job creation and job destruction in our framework. Spillover effects, whereby the actions of one set of firms affects the outcomes of another set of firms, are also required. To illustrate this point, consider a situation where firms within an industry sell a similar, but not necessarily identical, product. The demand for each of these different products increases with a depreciation in the exchange rate and decreases with an appreciation, although the size of the response varies widely across the set of products. When firms face a perfectly elastic supply of all inputs, a depreciation causes job creation among all firms while an appreciation causes job destruction among all firms.

However, in the polar case where labor supply to the industry as a whole is perfectly inelastic, the expansion of workers employed by one firm must come at the expense of the number of workers hired by another firm. In this case, a depreciation leads to both job creation, among firms that experience the greatest relative increase in demand for their goods, and job destruction, among firms with the smallest relative increase in demand for their goods. There is no job creation or job destruction when all firms respond in exactly the same way to a given change in the exchange rate. Therefore, in this case, the amount of reallocation is tied to the extent of heterogeneity among firms within the industry.

This pattern of simultaneous creation and destruction need not hold in the more general case where a shift in the industrywide demand for labor elicits a supply response. For example, with a sufficient labor supply response, a depreciation can lead to industrywide job creation and no job destruction, while an appreciation can lead to industrywide job destruction and no job creation.

The main themes of this illustration, the role of heterogeneity and spillover effects, can be made more explicit and a bit more general through a simple model. Assume that the cost function for the $i^{\text {th }}$ firm in an industry is

$$
C_{i}\left(W_{i}, G_{i} ; Q i\right)=A_{i} W_{i}^{\alpha} G_{i}^{(1-\alpha)} Q_{i}
$$

where $W_{i}$ is the wage paid by the firm, $G_{i}$ is the unit cost of its non-labor input, $Q_{i}$ is the output of the firm and $A_{i}$ is a constant for the $i^{t h}$ firm. By Shepard's lemma, the demand for labor by this firm, $L_{i}^{d}$ is the partial derivative of the cost function with respect to wages, that is

$$
L_{i}=\frac{\partial C_{i}\left(W_{i}, G_{i} ; Q i\right)}{\partial W_{i}}=\alpha A_{i} W_{i}^{\alpha-1} G_{i}^{(1-\alpha)} Q_{i}
$$

Then the total differential of the logarithm of labor demand equation (4), $d \ln L_{i}$ 
equals $^{11}$

$$
d \ln L_{i}=d \ln \left(A_{i}+\alpha\right)-(1-\alpha) d \ln W_{i}+(1-\alpha) d \ln G_{i}+d \ln Q_{i} .
$$

We introduce heterogeneity here by assuming differences in the demand for the products of the firms. ${ }^{12}$ Assume that the demand for the products of the $i^{t h}$ firm is given by the function

$$
Q_{i}=\left[\left(\frac{P_{i}}{P_{D}}\right)^{-\mu\left(1-X_{i}\right)} Y^{\beta\left(1-X_{i}\right)}\right]\left[\left(\frac{P_{i}}{E P^{*}}\right)^{-\mu X_{i}} Y^{* \beta X_{i}}\right]
$$

where $P_{D}$ is the price of a domestic good that is a potential substitute, $E$ is the exchange rate (expressed as domestic currency per unit of foreign currency), $P^{*}$ is the price of a foreign good that is a potential substitute, $Y$ is a measure of domestic income, $Y^{*}$ is a measure of foreign income, and $X_{i}$ is a parameter capturing the extent to which the $i^{\text {th }}$ firm face foreign competition either through sales abroad or through competition with imports. The own-price elasticity of demand for the firm's product is $-\mu$, and the cross-price elasticities of demand for the domestic and the foreign goods are $\mu\left(1-X_{i}\right)$ and $\mu X_{i}$, respectively. The total differential of the logarithm of the functional form given in (6) is

$$
\begin{aligned}
d \ln Q_{i}= & -\mu d \ln P_{i}+\mu\left(1-X_{i}\right) d \ln P_{D}+\mu X_{i} d \ln E \\
& +\mu X_{i} d \ln P^{*}+\beta\left(1-X_{i}\right) d \ln Y+\beta X_{i} d \ln Y^{*}
\end{aligned}
$$

Notice that here the heterogeneity of firms within a sector with respect to foreign competition is captured by the parameter $X_{i}$, while all firms in the sector have a

\footnotetext{
${ }^{11}$ Notice that, with this functional form, the cross-partial elasticity of the demand for labor is positive and, therefore, labor and the intermediate input are, what is called by Hamermesh (1993, p. 37), p-substitutes. An increase in the price of the intermediate input shifts out the demand for labor although the actual amount of labor hired by a firm will also depend upon labor supply considerations.

${ }^{12}$ Another possible source of heterogeneity is different upstream demands for foreign inputs, domestic inputs, and labor across the $N$ firms within an industry. One way to model this is to assume that the $i^{t h}$ firm in the industry uses $L_{i}$ units of labor, $I_{i}^{*}$ units of foreign inputs, and $I_{i}$ units of domestic inputs. Its production function is

$$
Q_{i}=A_{i} L_{i}^{\alpha}\left(I_{i}^{*}\right)^{F_{i}(1-\alpha)} I_{i}^{\left(1-F_{i}\right)(1-a)}
$$

where $Q_{i}$ is the number of units of output by that firm and the parameter $F_{i}$ indexes the extent to which the firm uses foreign inputs with $0<F_{i}<1$ for any $i$. The $F_{i}$ parameters may differ across all firms within a sector.
} 
common $\mu$. Substituting (7) into (5) gives us the labor demand equation for the $i^{\text {th }}$ firm

$$
\begin{aligned}
d \ln L_{i}= & d \ln \left(A_{i}+\alpha\right)-(1-\alpha) d \ln W_{i}+\mu X_{i} d \ln E \\
& +(1-\alpha) d \ln G_{i}-\mu d \ln P_{i}+\mu\left(1-X_{i}\right) d \ln P_{D} \\
& +\mu X_{i} d \ln P^{*}+\beta\left(1-X_{i}\right) d \ln Y+\beta X_{i} d \ln Y^{*}
\end{aligned}
$$

This equation demonstrates the positive direct effects of a depreciation of the exchange rate on labor demand since, for all firms in the industry, $\mu X_{i} \geq 0$.

The overall effect of a change in the exchange rate also depends upon indirect effects whereby the change in labor demand by one firm spills over to affect the number of jobs created or destroyed by another firm in that industry. In this case, spillover effects work through the influence of one firm's labor demand on wages faced by other firms. Assume that all firms within an industry pay the same wage so, for example, $W_{i}=W^{A}$ in industry $A$ for all $i$. We also assume some substitutability among workers in industry $A$ and workers in the rest of the economy such that the labor supply equation facing the $i^{\text {th }}$ firm in Industry $A$ is

$$
L_{i}=\left(\frac{W^{A}}{\bar{W}^{\varepsilon}}\right)^{\gamma}
$$

where $W^{A}$ is the industry-wide wage, $\bar{W}$ is the prevailing wage in the "rest of the economy," $\gamma$ is a measure of labor supply elasticity $(\gamma \geq 0)$, and $\varepsilon$ is a measure of the cross-elasticity of labor supply between Industry $A$ and the rest of the economy, with $\varepsilon \geq 0$. This specification gives us the total differential of labor supply facing the $i^{\text {th }}$ firm,

$$
d \ln L_{i}=\gamma\left(d \ln W^{A}-\varepsilon d \ln \bar{W}\right) .
$$

To focus on the effect of a change in the exchange rate, we assume that all other variables are constant to obtain a simple form of the labor demand equation $(8)^{13}$

$$
d \ln L_{i}=-(1-\alpha) d \ln W_{i}+\mu X_{i} d \ln E .
$$

Define $\omega_{i}$ as the relative employment size of the $i^{\text {th }}$ firm in Industry $A$ where $\sum_{i=1}^{N} \omega_{i}=1$. Then the change in the logarithm of the total demand for labor in

\footnotetext{
${ }^{13} \mathrm{We}$ assume here that $N$ is large such that all firms are price takers in the market for goods and in the market for inputs and that $d \ln P_{i}=0$ and $d \ln G_{i}=0$.
} 
Industry $A, d \ln L^{A}$, is

$$
\sum_{i=1}^{N} \omega_{i} d \ln L_{i} \equiv d \ln L^{A}=\left(\sum_{i=1}^{N} \omega_{i} X_{i} \mu\right) d \ln E-(1-\alpha) d \ln W^{A}
$$

where we have used

$$
\sum_{i=1}^{N} \omega_{i} d \ln W_{i}=\sum_{i=1}^{N} \omega_{i} d \ln W^{A}=d \ln W^{A} .
$$

Define the sectoral weighted average, $\bar{X}$, as

$$
\bar{X}=\sum_{i=1}^{N} \omega_{i} X_{i}
$$

We set labor demand equal to labor supply for Industry $A$ to solve for the industrywide wage as a function of the exchange rate and the economywide wage. ${ }^{14}$ Using this result, we have the $i^{t h}$ firm's rate of job creation (if $d \ln L_{i}>0$ ) or job destruction (if $d \ln L_{i}<0$ ) as

$$
d \ln L_{i}=\left\{\left[\mu\left(X_{i}-\bar{X}\right)\right]+\left[\frac{\gamma \mu \bar{X}}{(1-\alpha)+\gamma}-\frac{(1-\alpha) \varepsilon \gamma}{(1-\alpha)+\gamma} d \ln \bar{W}\right]\right\} d \ln E .
$$

Note that this result shows that the degree to which proportional changes in the exchange rate, $d \ln E$, lead to job creation or job destruction depends upon both the heterogeneity among firms within the industry (that is, the extent to which the individual $X_{i}$ 's differ from the average $\bar{X}$ ) and the general openness of the industry (the value of $\bar{X}$ itself).

\footnotetext{
${ }^{14}$ The steps involved include setting industry supply equal to industry demand,

$$
\gamma\left(d \ln W^{A}-\varepsilon d \ln \bar{W}\right)=-(1-\alpha) d \ln W^{A}+(\bar{F}(1-\alpha)+\mu \bar{X}) d \ln E
$$
}

which can be solved for $d \ln W^{A}$

$$
d \ln W^{A}=\frac{\gamma \varepsilon d \ln \bar{W}+(\bar{F}(1-\alpha)+\mu \bar{X})}{(\gamma+(1-\alpha))} d \ln E .
$$


This result allows for a range of possible results. To illustrate this, first consider the case where $\gamma=0$ and therefore $d \ln L^{A}=0$. Then we have the simple version of (12)

$$
d \ln L_{i}=\mu\left(X_{i}-\bar{X}\right) d \ln E .
$$

An exchange rate depreciation causes job creation for all firms with values of $X_{i}$ above the sector's average, and job destruction for all firms with values of $X_{i}$ below the sector's average. Firms with high relative sensitivity to exchange rate movements draw labor away from firms that respond less to movements in the exchange rate.

Gross job creation for Sector $A$, denoted $C$, is the weighted sum of the job creation rates of all $M$ firms expanding employment,

$$
C=\sum_{i=1}^{M} \omega_{i} d \ln L_{i}=\sum_{i=1}^{M} \omega_{i} \mu\left(X_{i}-\bar{X}\right) d \ln E
$$

while the job destruction rate, $D$, is the weighted sum of all $N-M$ firms with a contraction in employment,

$$
D=-\sum_{i=1}^{N-M} \omega_{i} d \ln L_{i}=-\sum_{i=1}^{N-M} \omega_{i} \mu\left(X_{i}-\bar{X}\right) d \ln E .
$$

Note that the job creation and job destruction rates depend upon the degree of heterogeneity across firms with respect to the parameter $X$.

The simple version of the firm's equilibrium labor input, equation (13), assumes $d \ln L^{A}=0$ and necessarily generates simultaneous creation and destruction in a sector since there are only intrasectoral job flows. We can incorporate intersectoral job flows by setting $\gamma>0$. In this case, it is possible to have only job creation or only job destruction in Sector $A$ in response to a change in the exchange rate. Consider the case where there is no heterogeneity in the sector, so $X_{i}=\bar{X}$ for all $i$. We then have job creation among all (identical) firms if

$$
\gamma \mu \bar{X}>(1-\alpha) \varepsilon \gamma d \ln \bar{W}
$$

and job destruction if the inequality sign goes the other way. This result shows that we can conceptually separate intrasectoral job flows from intersectoral job flows. Intrasectoral job flows reflect heterogeneity among firms in the sector. Intersectoral job flows reflect heterogeneity between the sector as a whole and the rest of the economy. 


\section{Regression Implementation and Results}

The model discussed above offers a general framework for our empirical specification. In this section we address several issues that are necessary for using that general framework to develop and implement a specification that we can use in our empirical analysis. We draw on the insights of both the model presented in Section 3 and the statistics presented in Section 2.

\subsection{Empirical Implementation}

The central issue in implementing the model concerns the manner in which we control for heterogeneity across industries in their responsiveness to movements in the real exchange rate. A standard way to control for differences in structure in a time series cross-section data set like ours is to run separate regressions for each set of 2-digit SIC industries; in this case we might choose to run 20 separate time-series cross-section regressions, one for each of the 2-digit manufacturing industries, with a cross-sectional component ranging from four 4-digit industries for the 2-digit industry Tobacco Products (SIC 21) to forty-seven 4-digit industries for the 2-digit industry Food and Kindred Products (SIC 20).

But our model suggests that the main source of heterogeneity across industries in the response to real exchange rate movements is differences in the degree of openness across industries. The response of job flows to the real exchange rate is likely to increase with the degree of openness of an industry. ${ }^{15}$ The traditional approach of estimating separate regressions for each 2-digit industry assumes a rough comparability among all 4-digit industries within a 2-digit category with respect to their degree of openness. Statistics presented in Section 2 indicate, however, pervasive heterogeneity with respect to openness across the sets of 4digit industries that constitute the respective 2-digit groupings. This suggests that an effort to control for heterogeneity with respect to openness by running separate regressions for each 2-digit industry is not likely to be successful.

An alternative approach is to use the entire sample in a regression but to control for openness through the use of an interactive variable. In the model presented

${ }^{15}$ Note that the cross partial derivative of equation (12) is

$$
\frac{\partial^{2} \ln L_{i}}{\partial \ln E \partial \ln X_{i}}>0
$$

indicating that the responsiveness of employment of the $i^{\text {th }}$ firm increases with respect to its measure of openness, $X_{i}$. 
above, we have

$$
d \ln L_{i t}=\ldots+\mu X_{i t} d \ln E_{t}+\ldots
$$

where we have added a time subscript. The coefficient on the proportional change in the exchange rate includes $X_{i t}$, which represents the degree of openness of firm $i$. This specification does not force common, and probably unwarranted, responses across 4-digit industries within a 2-digit industry group.

Following this approach, we estimate regressions of the form:

$$
\begin{aligned}
\left\{\begin{array}{c}
C_{i t} \\
D_{i t}
\end{array}\right\}= & \sum_{s=t-1}^{t}\left[\beta_{1} d \ln E_{s, s \in A}+\beta_{2} d \ln E_{s, s \in D}+\beta_{3} X_{i t} d l n E_{s, s \in A}\right. \\
& \left.+\beta_{4} X_{i t} d l n E_{s, s \in D}+\boldsymbol{\beta}_{\mathbf{5}} \boldsymbol{V}_{\boldsymbol{s}}+\boldsymbol{\beta}_{\mathbf{6}} \boldsymbol{Z}_{i \boldsymbol{s}}\right]+\alpha_{i}+\nu_{t}+\epsilon_{i t}
\end{aligned}
$$

where $i$ indexes 4-digit industries and $t$ indexes years. The dependent variables, $C_{i t}$ and $D_{i t}$, are annual rates of job creation and job destruction. Because of heterogeneity of firms and plants within 4-digit industries, during any given year there is likely to be simultaneous job creation and destruction. Previous research has demonstrated that job destruction is much more sensitive than job creation to changes in business cycle conditions, and it is of interest to investigate if this relationship also holds for changes in the real exchange rate. ${ }^{16}$

In constructing the real exchange rate change variables, we have split the sample period into two mutually exclusive subsets: years in which the dollar appreciated, $\{A\}$, and years in which the dollar depreciated, $\{D\}$. The variable $d \ln E_{t, t \in A}$ is set equal to the percentage change in the value of the dollar for years in which the dollar appreciated relative to other currencies, and is set equal to 0 for years in which the dollar depreciated. Likewise, $d \ln E_{t, t \in D}$ equals the percentage change in the value of the dollar for years in which the dollar depreciated and equals 0 in other years $\left(d \ln E_{t, t \in A} \geq 0\right.$ and $\left.d \ln E_{t, t \in D} \leq 0\right)$. The primary

\footnotetext{
${ }^{16}$ Gourinchas (1998) also studied the effect of the exchange rate on job creation and job destruction in U.S. manufacturing industries. He regressed job creation and job destruction on, among other aggregate variables, the deviation of industry-specific log real exchange rates from their trend values. Separate regressions were run on sectors identified as "traded goods sectors," (which is composed of the two groups "export sectors" and "import-competing sectors") and "non-traded goods sectors." Gourinchas discards from his sample all 4-digit industries that do not consistently, over the entire sample, fit his definition of export, import-competing or non-traded. This leaves him with 35 non-traded 4-digit industries and 68 traded 4-digit industries out of the initial 450 4-digit industries, a subsample with about 27 percent of the employment of the original sample.
} 
motivation for splitting the exchange rate movements into periods of appreciation and depreciation is data-based; in preliminary tests of our model we found important asymmetries between the effects of exchange rate appreciation and depreciation. Possible reasons for these asymmetries are discussed in conjunction with the regression results in the next section.

Our openness variable requires some explanation. Our intent in including this variable is to capture heterogeneity across industries in the degree of response to the real exchange rate. However, as we documented earlier, openness has increased sharply over time. To avoid confusing heterogeneity over industries with the effects of increasing openness (or other trending variables), it is desirable to use a detrended transformation of openness in the regressions. In constructing the openness variable that we include in the regressions $\left(X_{i t}\right)$, we start by calculating the value of exports plus imports as proportion of total shipments (domestic sales and exports) plus imports for each 4-digit manufacturing industry in each year. We then transform that measure by dividing it by the mean value of openness over all industries in the same year. This converts openness into a relative measure, which has a mean (over all industries) equal to one in each year. We then calculate a five- (previous) year moving average of the relative openness measure in order to avoid short-term fluctuations in openness from having an undue influence on our results. Although there is some variation over time in industries' relative degree of openness, the transition matrix results in Table 3 suggest that this is small relative to the cross-sectional variance over industries.

Other measured variables that influence job creation and destruction are included in the $\boldsymbol{V}_{\boldsymbol{t}}$ and $\boldsymbol{Z}_{i \boldsymbol{t}}$ vectors. Vector $\boldsymbol{V}_{\boldsymbol{t}}$ contains two aggregate variables: the percentage rates of change in U.S. GDP and OECD GDP. Vector $\boldsymbol{Z}_{i t}$ contains the percentage rates of change of variables that vary both over industries and over time. These include the real price of shipments, the real price of energy inputs, the real price of materials, and the real wages of production workers, all from the NBER Productivity Database. Descriptive statistics for the variables included in the regressions are displayed in Table 4.

The last three terms in equation 14, $\left(\alpha_{i}+\nu_{t}+\epsilon_{i t}\right)$, represent the effects of unmeasured influences on job creation and destruction at the industry, aggregate, and time-varying industry levels. We specify $\alpha_{i}$ to be a fixed (non-stochastic) effect, and treat $\nu_{t}$ and $\epsilon_{i t}$ as stochastic. The presence of $\nu_{t}$ implies non-independence of the regression error term across observations for any given year. Our estimated standard errors correct for this. ${ }^{17}$

\footnotetext{
${ }^{17}$ Failure to correct for non-independence of regression errors arising from unmeasured aggre-
} 
Table 4: Regression Variable Statistics

\begin{tabular}{lrr}
\hline & & $\begin{array}{c}\text { Standard } \\
\text { Deviation }\end{array}$ \\
\hline Aggregate variables: & & \\
Real exchange rate $(1973=100)$ & 97.5 & 14.3 \\
Real exchange rate growth & -.26 & 9.54 \\
Real exchange rate appreciation & 3.19 & 4.73 \\
Real exchange rate depreciation & -4.17 & 6.30 \\
U.S. GDP growth & 2.63 & 2.29 \\
OECD GDP growth & 3.34 & 1.59 \\
\hline Panel variables: & & \\
Creation & 8.61 & 5.15 \\
Destruction & 10.53 & 6.79 \\
Net growth & -1.92 & 8.63 \\
Openness (transformed) & 1.00 & .894 \\
Real shipments price growth & -.24 & 6.42 \\
Real energy price growth & 2.54 & 9.67 \\
Real materials price growth & .33 & 5.71 \\
Real wage growth & 1.08 & 7.70 \\
\hline
\end{tabular}

Note: All data are annual. The sample period is 1974-93 for all variables except the level of the exchange rate, which is 1973-93. Aggregate variables have 20 observations ( 21 for the exchange rate level). Panel data include 442 4-digit industries and 7,938 usable observations after excluding those with missing values.

\subsection{Regression Results}

Results from estimation of the regressions implied by equation 14 are shown in Table 5. The regressions were estimated using ordinary least squares, with nonindependence of the regression errors within years allowed for in computing the standard errors. ${ }^{18}$ A full set of 4-digit industry fixed effects, $\alpha_{i}$, were controlled for in the estimation. This allows each industry to have different base, or normal, rates of job creation and destruction. The point estimates are the sums of all lagged coefficients (including contemporaneous values where used).

Two important asymmetries in the response of employment to movements in the real exchange rate are apparent in the results. First, although job destruction gate effects in panel regressions with aggregate regressors can result in substantial understatement 
Table 5: Job Flows Regression Results

\begin{tabular}{|c|c|c|c|}
\hline & Creation & Destruction & Net Change \\
\hline Exchange rate appreciation & $\begin{array}{l}-.097 \\
(.077)\end{array}$ & $\begin{array}{r}.386 \\
(.070)\end{array}$ & $\begin{array}{l}-.482 \\
(.140)\end{array}$ \\
\hline Exchange rate depreciation & $\begin{array}{r}.006 \\
(.047)\end{array}$ & $\begin{array}{r}-.042 \\
(.063)\end{array}$ & $\begin{array}{r}.048 \\
(.099)\end{array}$ \\
\hline Appreciation x Openness & $\begin{array}{r}-.015 \\
(.019)\end{array}$ & $\begin{array}{r}.086 \\
(.017)\end{array}$ & $\begin{array}{l}-.101 \\
(.031)\end{array}$ \\
\hline Depreciation x Openness & $\begin{array}{r}.005 \\
(.014)\end{array}$ & $\begin{array}{r}.033 \\
(.016)\end{array}$ & $\begin{array}{r}-.028 \\
(.023)\end{array}$ \\
\hline U.S. GDP & $\begin{array}{r}.116 \\
(.182)\end{array}$ & $\begin{array}{r}-.278 \\
(.173)\end{array}$ & $\begin{array}{r}.394 \\
(.320)\end{array}$ \\
\hline OECD GDP & $\begin{array}{r}-.605 \\
(.358)\end{array}$ & $\begin{array}{r}.097 \\
(.229)\end{array}$ & $\begin{array}{l}-.702 \\
(.537)\end{array}$ \\
\hline Shipments prices & $\begin{array}{r}.095 \\
(.046)\end{array}$ & $\begin{array}{l}-.088 \\
(.043)\end{array}$ & $\begin{array}{r}.184 \\
(.078)\end{array}$ \\
\hline Energy prices & $\begin{array}{r}.079 \\
(.035)\end{array}$ & $\begin{array}{r}-.008 \\
(.047)\end{array}$ & $\begin{array}{r}.087 \\
(.073)\end{array}$ \\
\hline Materials prices & $\begin{array}{r}.061 \\
(.021)\end{array}$ & $\begin{array}{r}-.034 \\
(.024)\end{array}$ & $\begin{array}{r}.096 \\
(.041)\end{array}$ \\
\hline Average hourly earnings & $\begin{array}{r}-.002 \\
(.028)\end{array}$ & $\begin{array}{r}-.000 \\
(.029)\end{array}$ & $\begin{array}{r}-.001 \\
(.048)\end{array}$ \\
\hline $\begin{array}{l}R^{2} \\
\text { Observations }\end{array}$ & $\begin{array}{r}.133 \\
7938\end{array}$ & $\begin{array}{r}.147 \\
7938\end{array}$ & $\begin{array}{r}.169 \\
7938\end{array}$ \\
\hline
\end{tabular}

Note: Standard errors are in parentheses. All variables are growth rates except openness. Fixed effects for 4-digit industries are included. Shipments prices, energy prices, materials prices, and average hourly earnings are the sum of one and two lagged periods. All other variables are for the current and lagged periods. 
is sensitive to exchange rate movements, job creation is not. Second, the rate of job destruction increases with an increase in the value of the dollar, but job destruction does not decrease below normal levels when the dollar drops in value. As expected based on our model, the degree of sensitivity of job destruction to exchange rate movements increases with the degree of the industry's exposure to trade. ${ }^{19}$

We calculate the sensitivity of job destruction to an appreciation of the dollar by adding to the coefficients on "appreciation" the product of the openness measure and the coefficient on "openness times appreciation." The openness measure is constructed such that its mean value equals 1 in each year. These results reflect sensitivity of job destruction to the real exchange rate; an industry with an average degree of openness will, on average and all else equal, experience a 0.47 percentage point increase in job destruction for each percentage point of appreciation. Recall that it is not unusual to have a 10 percent appreciation rate in a given year and, in those years, we estimate that a typical industry experiences an almost 5 percentage point increase in job destruction due to the appreciation.

These results also reflect an important role for dollar appreciation in generating heterogeneous job destruction rates across industries. For example, the value of the relative openness measure for the lower quartile of industries is 0.34 for the period 1974 to 1993, while the value of openness for the upper quartile over the same period is 1.42 . These differences translate to estimated partial derivatives of job destruction with respect to an appreciation of 1 percentage point in the real exchange rate of 0.415 and 0.508 , respectively, values even larger and more significant than the partial derivatives with respect to U.S. GDP. Thus, a firm at the upper quartile of openness will have a 22 percent larger increase in job destruction than a firm at the lower quartile of openness, all else equal.

The asymmetry between the responsiveness of job creation and job destruction has been found in other contexts as well. In particular, job destruction is much more sensitive to business cycle conditions than is job creation. Thus, one possi-

\footnotetext{
of the standard errors associated with those regressors; see Kloeck (1981) or Moulton(1990).

${ }^{18}$ Estimation of the same equations using an error components model allowing for random year effects in computing the regression coefficients produces very similar results.

${ }^{19}$ Gourinchas (1998), using a different framework and a smaller set of industries (see footnote 16), finds a significant response of both job destruction and job creation to the real exchange rate. Surprisingly, he finds job creation and job destruction move significantly in the same direction in response to a given exchange rate change. The standard errors he reports, however, do not control for the possibly high covariance of industry exchange rates when calculating standard errors (see Moulton 1990).
} 
ble explanation for the results in Table 5 is that exchange rate movements represent aggregate shocks that trigger asymmetric creation and destruction responses because of underlying microeconomic nonlinearities in employment adjustment behavior. $^{20}$

An alternative explanation of the asymmetry between the responsiveness of job creation and destruction is that, at the plant level, job creation may respond to shocks with a longer and more variable time lag than does job destruction. ${ }^{21} \mathrm{Em}$ ployees can be discharged nearly immediately after a firm has determined that it is optimal to do so, but expanding employment often requires considerable planning, screening of new employees, installation of new equipment, and sometimes erection of new structures. Furthermore, there may be fixed costs, periods of learning, and other barriers to entering foreign markets or expanding one's presence abroad. Because of these potential delays, it may be difficult to detect the response of job creation to a change in the real exchange rate even if the response does exist.

The coefficients on most of the other variables are not statistically significant. An exception is the growth rate of the price of the industry's shipments, which is significant in both the job creation and job destruction regressions. An increase in the real price of shipments, which one would expect to increase industry profits, increases job creation and reduces job destruction.

The last column of the table shows the result of regressing net employment change on the independent variables or, equivalently, the result of subtracting the job destruction coefficients from the job creation coefficients. The exchange rate coefficients in this column are largely driven by the coefficients from the job destruction regression. This illustrates the importance of analyzing job creation and destruction, rather than just net changes in employment. The "net employment change" column shows that an appreciation of the dollar results in a large and statistically significant reduction in employment. But it misses the important fact that the main way in which this is achieved is through an increase in job destruction, with relatively little contemporaneous change in job creation. The reason this fact is important is that changes in job destruction are likely to have more serious effects on wages and unemployment rates.

In estimating the regressions reported in Table 5, all industries were given equal weight, regardless of their size. If the true population regression coefficients vary over industries in a way not completely captured by the interaction

\footnotetext{
${ }^{20}$ Papers that advance this hypothesis include Caballero and Engel (1993), Caballero, Engel and Haltiwanger (1997), Foote (1998), and Campbell and Fisher (1997).

${ }^{21}$ We control for lags by including both contemporaneous and lagged values of the annual percentage changes in the real exchange rate in job creation and job destruction regressions.
} 
between the exchange rate change variables and openness, then using the coefficients in Table 5 to forecast the aggregate changes in job creation and destruction due to a change in the real exchange rate will produce biased estimates. To gauge the potential importance of this problem, and to probe the robustness of our results, we reestimated the regressions weighting each industry observation by its employment size. The results from this exercise are reported in Table 6 . The differences between Tables 5 and 6 are relatively minor. In particular, the responses of job creation and destruction to changes in the real exchange rate are similar in the two sets of regressions.

The results in Table 6 can be used to estimate the overall effect in the manufacturing sector of a change in the value of the dollar. For example, as stated earlier, the dollar appreciated from 1982 to 1986 at an annual rate of 8.9 percent per year. The estimates in Table 6 suggest that, over this period, the appreciation of the dollar was responsible for an increase in the job destruction rate of 3.6 percentage points each year, for a total estimated increase due to the 35.6 percent appreciation of 14.4 percentage points. The total increase in the job destruction rate due to the appreciation among firms at the lower quartile of openness ( $X=0.34$ for this period) was about 13 percentage points while the total increase in the job destruction rate due to the appreciation among firms at the upper quartile of openness ( $X=1.41$ for this period) was about 15.4 percentage points.

One possible reason we do not find that job destruction is sensitive to the exchange rate in years when there was a depreciation may be that the dollar was quite high relative to historical values during its steep depreciation after the mid 1980s. Although some firms likely responded to the depreciation by decreasing their rate of job destruction at that time, others may have continued to destroy jobs at a faster than normal rate because of the high value of the dollar. The asymmetry between the effects of exchange rate appreciations and depreciations in the regression results shown in Tables 5 and 6 may reflect a role for the level of the exchange rate relative to its long-run equilibrium value in determining rates of job creation and destruction.

To investigate this hypothesis, we estimated regressions in which the exchange rate change variables were replaced by the log-level of the exchange rate $\left(\ln E_{t}\right)$. The log-level of the exchange rate coefficient can be interpreted as showing the effect of deviations of the exchange rate from its equilibrium value, with the equilibrium value being incorporated into the constant term and random year effects.

The results of estimating the new specification, which are shown in Table 7, are broadly consistent with the earlier specification. As before, the real exchange rate affects job destruction but not job creation. Rates of job destruction will be 
Table 6: Job Flows Regressions Results, Employment Weighted

\begin{tabular}{|c|c|c|c|}
\hline & Creation & Destruction & Net Change \\
\hline Exchange rate appreciation & $\begin{array}{r}-.047 \\
(.077)\end{array}$ & $\begin{array}{r}.345 \\
(.065)\end{array}$ & $\begin{array}{l}-.392 \\
(.138)\end{array}$ \\
\hline Exchange rate depreciation & $\begin{array}{r}.032 \\
(.051)\end{array}$ & $\begin{array}{r}-.003 \\
(.053)\end{array}$ & $\begin{array}{r}.035 \\
(.097)\end{array}$ \\
\hline Appreciation x Openness & $\begin{array}{l}-.029 \\
(.022)\end{array}$ & $\begin{array}{r}.062 \\
(.026)\end{array}$ & $\begin{array}{l}-.091 \\
(.045)\end{array}$ \\
\hline Depreciation x Openness & $\begin{array}{r}.004 \\
(.025)\end{array}$ & $\begin{array}{r}.008 \\
(.021)\end{array}$ & $\begin{array}{r}-.012 \\
(.043)\end{array}$ \\
\hline U.S. GDP & $\begin{array}{r}.188 \\
(.175)\end{array}$ & $\begin{array}{r}-.336 \\
(.161)\end{array}$ & $\begin{array}{r}.524 \\
(.318)\end{array}$ \\
\hline OECD GDP & $\begin{array}{c}-.602 \\
(.356)\end{array}$ & $\begin{array}{r}.150 \\
(.245)\end{array}$ & $\begin{array}{l}-.752 \\
(.576)\end{array}$ \\
\hline Shipments prices & $\begin{array}{r}.088 \\
(.068)\end{array}$ & $\begin{array}{r}-.126 \\
(.062)\end{array}$ & $\begin{array}{r}.214 \\
(.120)\end{array}$ \\
\hline Energy prices & $\begin{array}{r}.106 \\
(.041)\end{array}$ & $\begin{array}{c}-.062 \\
(.050)\end{array}$ & $\begin{array}{r}.168 \\
(.085)\end{array}$ \\
\hline Materials prices & $\begin{array}{r}.074 \\
(.032)\end{array}$ & $\begin{array}{r}-.080 \\
(.035)\end{array}$ & $\begin{array}{r}.155 \\
(.061)\end{array}$ \\
\hline Average hourly earnings & $\begin{array}{r}-.035 \\
(.046)\end{array}$ & $\begin{array}{r}.013 \\
(.038)\end{array}$ & $\begin{array}{r}-.048 \\
(.077)\end{array}$ \\
\hline $\begin{array}{l}R^{2} \\
\text { Observations }\end{array}$ & $\begin{array}{r}.204 \\
7938\end{array}$ & $\begin{array}{r}.205 \\
7938\end{array}$ & $\begin{array}{r}.229 \\
7938\end{array}$ \\
\hline
\end{tabular}

Note: Standard errors are in parentheses. All variables are growth rates except openness. Fixed effects for 4-digit industries are included. Shipments prices, energy prices, materials prices, and average hourly earnings are the sum of one and two lagged periods. All other variables are for the current and lagged periods. 
greater than normal in years in which the exchange rate is above its equilibrium value. However, in the new specification the effect of the real exchange rate on job destruction does not vary significantly with the degree of the industry's openness to trade.

The robustness of the results were further checked by including the log-level of the exchange rate as an additional regressor in our earlier specification. ${ }^{22}$ In this case, in the job destruction regression the log-level of the exchange rate is positive and sizable, but statistically insignificant; the change in the real exchange rate is positive and significant for years in which the dollar appreciated and small and insignificant for years in which the dollar depreciated. Thus, while we can say with some confidence that an appreciation of the exchange rate results in an increased rate of job destruction, the role of the exchange rate level is not entirely clear. In addition, we are not able to resolve why a depreciation of the exchange rate does not result in a decreased rate of job destruction.

\section{Conclusion}

Movements in the real exchange rate have a substantial impact on the rate at which manufacturing jobs are destroyed. Specifically, we have shown that an appreciation of the dollar results in an increased rate of job destruction, with the largest increase coming in the most open industries. We do not find statistically significant evidence that dollar depreciation is associated with lower rates of job destruction, all else equal. Also, job creation seems to be little affected by exchange rate movements.

The welfare implications of this result are unclear. Many of the jobs destroyed when the dollar appreciates are likely to have been only marginally profitable, and may have been slated for eventual elimination even if the exchange rate remained stable. However, the timing of job destruction does have an impact on the welfare of displaced workers. Workers are likely to have an easier time finding suitable reemployment when job destruction is gradual and diffuse than when an external shock causes job destruction to spike and, consequently, a glut of displaced workers are searching for new jobs simultaneously. For this reason, acceleration of job destruction caused by a temporary appreciation of the exchange rate can have adverse consequences on economic welfare. Further research will be needed to quantify this effect.

\footnotetext{
${ }^{22}$ These results are not shown, but are available from the authors upon request.
} 
Table 7: Job Flows Regression Results, Alternative Specification

\begin{tabular}{|c|c|c|c|}
\hline & Creation & Destruction & Net Change \\
\hline $\ln ($ Real exchange rate $)$ & $\begin{array}{r}-1.44 \\
(2.58)\end{array}$ & $\begin{array}{l}12.44 \\
(2.13)\end{array}$ & $\begin{array}{r}-13.88 \\
(4.51)\end{array}$ \\
\hline $\begin{array}{c}\ln (\text { Real exchange rate } \\
\text { x openness })\end{array}$ & $\begin{array}{r}.189 \\
(.060)\end{array}$ & $\begin{array}{l}-.059 \\
(.082)\end{array}$ & $\begin{array}{r}.248 \\
(.128)\end{array}$ \\
\hline U.S. GDP & $\begin{array}{r}.156 \\
(.238)\end{array}$ & $\begin{array}{r}-.602 \\
(.235)\end{array}$ & $\begin{array}{r}.758 \\
(.416)\end{array}$ \\
\hline OECD GDP & $\begin{array}{r}-.612 \\
(.275)\end{array}$ & $\begin{array}{r}.601 \\
(.212)\end{array}$ & $\begin{array}{r}-1.213 \\
(.457)\end{array}$ \\
\hline Shipments prices & $\begin{array}{r}.082 \\
(.051)\end{array}$ & $\begin{array}{r}-.088 \\
(.063)\end{array}$ & $\begin{array}{r}.170 \\
(.105)\end{array}$ \\
\hline Energy prices & $\begin{array}{r}-.075 \\
(.036)\end{array}$ & $\begin{array}{r}.019 \\
(.045)\end{array}$ & $\begin{array}{r}.056 \\
(.075)\end{array}$ \\
\hline Materials prices & $\begin{array}{r}.033 \\
(.018)\end{array}$ & $\begin{array}{l}-.019 \\
(.025)\end{array}$ & $\begin{array}{r}.052 \\
(.038)\end{array}$ \\
\hline Average hourly earnings & $\begin{array}{r}.012 \\
(.020)\end{array}$ & $\begin{array}{r}-.036 \\
(.033)\end{array}$ & $\begin{array}{r}.048 \\
(.048)\end{array}$ \\
\hline$R^{2}$ & $\begin{array}{r}.119 \\
8820\end{array}$ & $\begin{array}{r}.155 \\
8820\end{array}$ & $\begin{array}{r}.169 \\
8820\end{array}$ \\
\hline
\end{tabular}

Note: Standard errors are in parentheses. All variables are growth rates except openness. Fixed effects for 4-digit industries are included. Shipments prices, energy prices, materials prices, and average hourly earnings are the sum of one and two lagged periods. All other variables are for the current and lagged periods. 
We have documented that the importance of trade in U.S. manufacturing has increased tremendously, along relatively idiosyncratic lines. Most of the variation in openness to trade is within, rather than between, major industry groups. Over time, the greatest increase in openness to trade has been in the industries that initially were most open. An interesting extension of this research would be to model the factors that underlie why particular 4-digit industries are much more open than are other industries in the same 2- or 3-digit industry group. 


\section{Bibliography}

Abowd, John M., "The NBER Immigration, Trade and Labor Markets Data Files," NBER Working Paper, no. 3351, May 1990.

Bartelsman, Eric J. and Wayne Gray, "The NBER Productivity Database," NBER Technical Working Paper, No. 205, 1996.

Bernard, Andrew and Bradford Jensen, "Exporters, Jobs and Wages in U.S. Manufacturing, 1976-1987”, Brookings Papers on Economic Activity, Microeconomics 1995, pp. 67-112.

Branson, William, and Jamie Love, "United States Manufacturing and the Real Exchange Rate," in Richard Marston, ed., Misalignment of Exchange Rates: Effects on Trade and Industry, University of Chicago Press, Chicago, Illinois, 1988.

Burgess, Simon and Michael Knetter, "An International Comparison of Employment Adjustment to Exchange Rate Fluctuations," Review of International Economics, vol. 6, February 1998, pp. 151-163.

Caballero, Ricardo J. and Eduardo M.R.A. Engel, "Microeconomic Adjustment Hazards and Aggregate Dynamics," Quarterly Journal of Economics, vol. 108, no. 2, 1993, pp.359-83.

and John C. Haltiwanger, "Aggregate Employment Dynamics:

Building from Microeconomic Evidence," American Economic Review, vol. 87, no. 1, 1997, pp. 115-37.

Campbell, Jeffrey R. and Jonas D.M. Fisher, "Aggregate Employment Fluctuations with Microeconomic Asymmetries," Working Paper WP-96-17, Federal Reserve Bank of Chicago, 1997.

Campa, Jose and Linda Goldberg, "Employment versus Wage Adjustment and the U.S. Dollar," mimeo, Federal Reserve Bank of New York, December 1997.

Davis, Steven J., John C. Haltiwanger and Scott Schuh, Job Creation and Destruction, MIT Press, Cambridge, Massachusetts, 1996.

Feenstra, Robert C., Robert E. Lipsey, and Harry P. Bowen, "World Trade Flows, 1970-1992, with Production and Tariff Data," NBER Working Paper, No. 5910, 1997.

Robert C. Feenstra, "NBER Trade Database, Disk1: U.S. Imports, 1972-1994: Data and Concordances," NBER Working Paper No. 5515, March 1996. 
Robert C. Feenstra, "NBER Trade Database, Disk 3: U.S. Exports, 1972-1994, with State Exports and Other U.S. Data," NBER Working Paper No. 5990, April 1997.

Foote, Christopher, "Trend Employment Growth and the Bunching of Job Creation and Destruction," Quarterly Journal of Economics, 1998, vol. 113, no. 3, pp. 809-834.

Grossman, Gene M., "The Employment and Wage Effects of Import Competition in the United States," NBER Working Paper, no. 1041, December 1982.

Gourinchas, Pierre-Olivier, "Exchange Rates and Jobs: What Do We Learn from Job Flows?" NBER Macroeconomics Annual 1998, The MIT Press, Cambridge, MA, pp. 153 - 207.

Hamermesh, Daniel S., Labor Demand, Princeton University Press, Princeton, N.J., c. 1993.

Kletzer, Lori G., "Trade and Job Loss in U.S. Manufacturing, 1975-1994," February 1998, mimeo, University of California, Santa Cruz.

Kloek, Teun, "OLS Estimation in a Model Where a Microvariable is Explained by Aggregates and Contemporaneous Disturbances are Equicorrelated," Econometrica, vol. 49, no. 1, January 1981, pp. 205-207.

Mortensen, Dale T. and Christopher A. Pissarides, "Job Creation and Destruction in the Theory of Unemployment," Review of Economic Studies, 1994, vol. 66, pp. 39 7-415.

Moulton, Brent, "An Illustration of a Pitfall in Estimating the Effects of Aggregate Variables on Micro Units," Review of Economics and Statistics, vol. 72, 1990, pp. 334-338.

Revenga, Ana, "Exporting Jobs? The Impact of Import Competition on Employment and Wages in US Manufacturing," Quarterly Journal of Economics, 1992, vol 107, no. 1, pp. 255-84.

Sachs, Jeffrey and Howard Shatz, "Trade and Jobs in U.S. Manufacturing," Brookings Papers on Economic Activity, 1994, no. 1, pp. 1-78.

Schuh, Scott and Robert Triest, "Job Reallocation and the Business Cycle: New Facts for an Old Debate," in Jeff Fuhrer and Scott Schuh, eds., Beyond Shocks: What Causes Business Cycles?, Federal Reserve Bank of Boston, 1998. 